\title{
Revolução Haitiana e as transformações da economia de plantation:
}

Saint-Domingue, 1790-1803

\section{Haitian Revolution and the transformations of plantation economy:}

Saint-Domingue, 1790-1803

Isabela Rodrigues de Souza ${ }^{1}$

Neste trabalho analisamos a economia do café e do açúcar na colônia francesa de SaintDomingue no intervalo de 1790 a 1803, isto é, no decurso do que posteriormente seria denominado Revolução Haitiana. Ele é desdobramento direto da pesquisa precedente de Iniciação Científica, na qual exploramos os censos dominiais e urbanos produzidos entre 1795 e 1803, uma documentação massiva e que até aquele momento tinha sido negligenciada pela historiografia - as tabulações produzidas com base nos dados dessa fonte foram complementadas e comparadas com as informações da ilha na véspera da revolução escrava, contidas no relato minucioso de Moreau de SaintMéry, e, em conjunto, possibilitaram uma delimitação mais precisa das trajetórias de recuperação e remodelação da cultura cafeeira e de derrocada da cultura açucareira.

Os impactos das guerras entre escravos, forças revolucionárias francesas, armadas britânica e espanhola ao longo de 13 anos de batalhas incontínuas, bem como a abolição geral dos cativos de 1794, transformaram profundamente a dinâmica produtiva na colônia, apesar dos esforços dos líderes negros, em especial Toussaint Louverture - principal figura revolucionária - em recuperar o sistema de plantations. A destruição dos engenhos de açúcar por meio de incêndios e pilhagem no início da revolução não foi o ponto final das exportações de commodities: o café, segundo produto de importância comercial em Saint-Domingue, não conheceu o destino fatalista das unidades açucareiras, conseguindo recuperar dois terços do cultivo pré-revolucionário sem o uso de mão-de-obra escravizada e em fazendas reorganizadas. Tal foi o sucesso que o comércio com os Estados Unidos aumentou neste período. E no caso da economia açucareira, mesmo com o resultado desastroso ao final da guerra de independência, as políticas econômicas motivaram uma relativa melhora no ano de 1802.

Pretendemos aprofundar os dados encontrados na pesquisa anterior com a leitura de relatos de contemporâneos ao evento (disponíveis em suporte online e nos Archives Nationales de Paris), dos arquivos notariais (depositados nos Archives Nationales d'Outre-Mer na França) e da legislação e outros textos legislativos revolucionários, a fim de compreender melhor o funcionamento do sistema de plantation em meio à revolução escrava.

Duas hipóteses guiam esta pesquisa: a participação no restabelecimento das plantations era mais generalizada do que imaginou a historiografia, incluindo não apenas o grupo de militares negros e mulatos de alto escalão, mas também os antigos donos, anciens libres, petits-blancs e até mesmo ex-escravos; e o parcelamento das fazendas cafeeiras se tornou uma prática no contexto da revolução, seja ele legal (promovido pelas políticas de arrendamento) ou ilicitamente (pelos 
maroons que viviam nas montanhas). Esperamos ao fim que, de maneira geral, possamos lançar luz para um entendimento renovado da Revolução Haitiana.

Palavras-chave: Revolução Haitiana; plantation; escravidão; café; açúcar.

Keywords: Haitian Revolution; plantation; slavery; coffee; sugar.

1 Mestranda em História Social na Universidade de São Paulo, bolsista Fapesp, integrante do Laboratório de Estudos sobre o Brasil e o Sistema Mundial (LabMundi-USP). 